\title{
31. COMPRESSIONAL WAVE VELOCITIES IN BASALT AND DOLERITE SAMPLES RECOVERED DURING LEG $15^{1}$
}

\author{
Paul J. Fox and Edward Schreiber, Lamont-Doherty Geological Observatory of Columbia University, Palisades, New York ${ }^{2}$
}

\section{INTRODUCTION}

The velocity of propagation of compressional waves was investigated in fifty-two samples of basalt and dolerite recovered during Leg 15 of the Deep Sea Drilling Project. Velocity measurements of the selected specimens were first conducted at atmospheric pressure and then at intervals of higher confining pressure up to $7 \mathrm{~kb}$. The velocity data presented here provide useful criteria for the correlation of rock types cored at Sites $146,150,151,152$, and 153 with seismic reflection, oblique reflection, and refraction profiles obtained from the Caribbean Basin.

\section{PROCEDURE}

Velocity measurements were performed using the modified pulse transmission method (Mattaboni and Schreiber, 1967) which was described in Volume 11 of the Initial Reports of the Deep Sea Drilling Project (Schreiber et al., 1972). The precision of our measurements is about 1 percent because of hysteresis observed between measurements performed under increasing and decreasing confining pressure. The hysteresis is caused by anelastic changes that occur within the specimen, and these changes are attributed to adjustments in the pore and crack geometry during the application of pressure.

Specimens one-half inch in diameter were cut from the cores in directions parallel to and perpendicular to the core axis in order to obtain information about possible velocity anisotropy. The ends of the specimens were trimmed flat to produce surfaces that were parallel to within $0.002 \mathrm{~cm}$. The bulk density of each specimen was calculated on the basis of its dimensional measurements and mass. The error in the density value is \pm 1 percent. Prior to measurement of the compressional wave velocities, the specimens were jacketed with 2-mil-thick copper foil which prevented pressurizing fluid from penetrating into pores or cracks present in the specimen. Thus the change in velocity as cracks and pores close under increasing pressure could be determined. Specimens were measured in the "as received" condition and were neither dried nor saturated prior to the velocity measurements.

\footnotetext{
${ }^{1}$ Lamont-Doherty Geological Observatory, Palisades, N.Y. Contribution No. 1792 .

${ }^{2}$ Paul J. Fox is also affiliated with the Department of Geology, State University of New York at Albany, Albany, New York 12203 and Edward Schreiber is also affiliated with the Department of Earth and Environmental Sciences, Queens College, Flushing, New
York 11367.
}

\section{RESULTS}

At Site 146, located in the center of the Venezuela Basin, sixteen meters of Coniacian dolerite were recovered 756 meters below the sediment-water interface. The fineto medium-grained dolerite is composed of equigranular, subophitic to ophitic intergrowths of plagioclase and augite with oxides and interstitial saponite (see Donnelly, "Basalts and Dolerites," for a complete discussion of petrology). The measured velocities of twenty-two specimens range from 4.39 to $5.57 \mathrm{~km} / \mathrm{sec}$ at $.25 \mathrm{~kb}$ to 5.26 to $6.03 \mathrm{~km} / \mathrm{sec}$ at $7 \mathrm{~kb}$ (Table 1). The calculated in situ confining pressure of the dolerite at Site 146 is approximately $0.5 \mathrm{~kb}$. The measured velocity range of the twenty-two specimens at $0.5 \mathrm{~kb}$ is 4.48 to $5.64 \mathrm{~km} / \mathrm{sec}$ and the average is 5.08 $\mathrm{km} / \mathrm{sec}$.

At Site 150 , located $35 \mathrm{~km}$ south of Site 146 in the Venezuela Basin, six meters of Coniacian dolerite were recovered 168 meters below the sediment-water interface. Although not as fresh as the dolerite of Site 146, the fineto medium-grained dolerite of Site 150 is composed of equigranular, subophitic to ophitic intergrowths of plagioclase and augite with oxides and interstitial saponite (see Donnelly, "Basalts and Dolerites," for a complete discussion of petrology). The measured velocities of twelve specimens range from 3.85 to $5.05 \mathrm{~km} / \mathrm{sec}$ at $0.25 \mathrm{~kb}$ to 5.06 to $5.76 \mathrm{~km} / \mathrm{sec}$ at $7 \mathrm{~kb}$ (Table 1). The calculated in situ confining pressure of the dolerite at Site 150 is approximately $0.4 \mathrm{~kb}$. The measured velocity range of the fifteen specimens at $0.4 \mathrm{~kb}$ is 4.03 to $5.12 \mathrm{~km} / \mathrm{sec}$ and the average is $4.78 \mathrm{~km} / \mathrm{sec}$.

At Site 151, located at the southern end of the Beata Ridge, two thin basalt sills of Santonian age were sampled 338 meters below the sediment-water interface. The amygdaloidal, slightly altered basalt is composed of glomeroporphyritic plagioclase set in a groundmass of plagioclase, pyroxene, oxide grains, and interstitial micaceous substance (see Donnelly, "Basalts and Dolerites," for a complete discussion of petrology). Only a small amount of basalt was recovered at Site 151 and consequently only four specimens were analyzed. The measured velocities of the four specimens range from 4.00 to $4.21 \mathrm{~km} / \mathrm{sec}$ at $0.25 \mathrm{~kb}$ to 4.81 to $5.17 \mathrm{~km} / \mathrm{sec}$ at $7 \mathrm{~kb}$ (Table 1). The calculated in situ confining pressure of the basalt at Site 151 is approximately $0.4 \mathrm{~kb}$. The measured velocity range of the four specimens at $0.4 \mathrm{~kb}$ is 4.09 to $4.32 \mathrm{~km} / \mathrm{sec}$ and the average is $4.19 \mathrm{~km} / \mathrm{sec}$.

At Site 152, located on the lower slope of the Nicaragua Rise at the Northern end of the Colombia Basin, twelve meters of Campanian basalt were sampled 473 meters below the sediment-water interface. The recovered basalt, like the slightly altered basalt of Site 151 , is amygdaloidal 
TABLE 1

Summary of Leg 15 Compressional Wave Velocities Measured for Basalt and Dolerite Samples. ${ }^{\text {a }}$

\begin{tabular}{|c|c|c|c|c|c|c|c|c|c|c|c|c|c|c|c|}
\hline \multirow[b]{2}{*}{ Sample } & \multirow[b]{2}{*}{$\begin{array}{l}\text { Orien- } \\
\text { tation }\end{array}$} & \multirow[b]{2}{*}{$\begin{array}{l}\text { Density } \\
\left(\mathrm{gm} / \mathrm{cm}^{3}\right)\end{array}$} & \multirow[b]{2}{*}{$\begin{array}{l}\text { Rock } \\
\text { Type }\end{array}$} & \multirow[b]{2}{*}{$1 \mathrm{~atm}}$. & \multirow[b]{2}{*}{0.25} & \multirow[b]{2}{*}{0.50} & \multirow[b]{2}{*}{0.75} & \multicolumn{6}{|c|}{ Confining Pressure } & \multirow[b]{2}{*}{6.00} & \multirow[b]{2}{*}{7.00} \\
\hline & & & & & & & & \multicolumn{6}{|c|}{$(\mathrm{kb})$} & & \\
\hline \multirow[t]{2}{*}{$146-41 \mathrm{R}-2(19-27)$} & Vert. & 2.81 & Dolerite & 4.22 & 4.59 & 4.76 & 4.87 & 4.97 & 5.10 & 5.20 & 5.37 & 5.48 & 5.55 & 5.62 & 5.67 \\
\hline & Horz. & 2.80 & Dolerite & 4.26 & 4.39 & 4.48 & 4.56 & 4.64 & 4.77 & 4.86 & 5.00 & 5.10 & 5.19 & 5.28 & 5.36 \\
\hline 146-41R-2(104-113) & Horz. & 2.74 & Dolerite & 4.42 & 4.60 & 4.68 & 4.75 & 4.80 & 4.91 & 5.00 & 5.12 & 5.23 & 5.32 & 5.38 & 5.43 \\
\hline $146-42 \mathrm{R}-1(27-33)$ & Vert. & 2.81 & Dolerite & 4.68 & 4.80 & 4.97 & 5.09 & 5.17 & 5.28 & 5.37 & 5.47 & 5.54 & 5.59 & 5.62 & 5.65 \\
\hline $146-42 \mathrm{R}-1(117-123)$ & Horz. & 2.88 & Dolerite & 5.00 & 5.14 & 5.20 & 5.25 & 5.30 & 5.38 & 5.45 & 5.58 & 5.68 & 5.77 & 5.85 & 5.91 \\
\hline \multirow[t]{2}{*}{$146-42 R-2(10-19)$} & Vert. & 2.88 & Dolerite & 4.84 & 5.08 & 5.17 & 5.25 & 5.31 & 5.41 & 5.48 & 5.60 & 5.67 & 5.71 & 5.74 & 5.76 \\
\hline & Horz. & 2.91 & Dolerite & 4.85 & 5.07 & 5.16 & 5.21 & 5.26 & 5.35 & 5.42 & 5.54 & 5.63 & 5.70 & 5.76 & 5.80 \\
\hline $146-42 \mathrm{R}-2(93-101)$ & Vert. & 2.87 & Dolerite & 5.00 & 5.20 & 5.28 & 5.32 & 5.38 & 5.46 & 5.52 & 5.63 & 5.71 & 5.78 & 5.84 & 5.89 \\
\hline $146-42 \mathrm{R}-3(28-37)$ & Vert. & 2.79 & Dolerite & 4.87 & 5.17 & 5.23 & 5.29 & 5.37 & 5.45 & 5.51 & 5.57 & 5.68 & 5.77 & 5.82 & 5.87 \\
\hline $146-42 R-3(135-145)$ & Vert. & 2.88 & Dolerite & 5.13 & 5.26 & 5.36 & 5.45 & 5.51 & 5.59 & 5.64 & 5.71 & 5.75 & 5.77 & 5.79 & 5.80 \\
\hline & Horz. & 2.89 & Dolerite & 5.02 & 5.14 & 5.21 & 5.27 & 5.32 & 5.41 & 5.48 & 5.61 & 5.70 & 5.78 & 5.82 & 5.85 \\
\hline $146-43 R-1(67-82)$ & Vert. & 2.84 & Dolerite & 4.71 & 5.02 & 5.12 & 5.18 & 5.24 & 5.32 & 5.38 & 5.45 & 5.50 & 5.53 & 5.55 & 5.57 \\
\hline & Horz. & 2.91 & Dolerite & 4.94 & 5.08 & 5.17 & 5.23 & 5.27 & 5.34 & 5.40 & 5.49 & 5.55 & 5.61 & 5.66 & 5.69 \\
\hline $146-43 R-1(144-151)$ & Vert. & 2.90 & Dolerite & 4.97 & 5.13 & 5.23 & 5.32 & 5.40 & 5.50 & 5.57 & 5.66 & 5.71 & 5.74 & 5.77 & 5.80 \\
\hline & Horz. & 2.85 & Dolerite & 4.80 & 4.92 & 5.04 & 5.13 & 5.20 & 5.31 & 5.40 & 5.50 & 5.56 & 5.61 & 5.66 & 5.70 \\
\hline $146-43 R-2(32-39)$ & Horz. & 2.93 & Dolerite & 5.30 & 5.37 & 5.43 & 5.49 & 5.53 & 5.60 & 5.66 & 5.75 & 5.81 & 5.87 & 5.93 & 5.98 \\
\hline $146-43 R-3(0-10)$ & Vert. & 2.91 & Dolerite & 4.98 & 5.18 & 5.27 & 5.33 & 5.38 & 5.46 & 5.52 & 5.61 & 5.66 & 5.69 & 5.71 & 5.72 \\
\hline & Horz. & 2.76 & Dolerite & 4.55 & 4.80 & 4.91 & 5.00 & 5.08 & 5.21 & 5.30 & 5.41 & 5.50 & 5.57 & 5.62 & 5.68 \\
\hline 146-43R-3-(119-131) & Vert. & 3.04 & Dolerite & 4.98 & 5.05 & 5.10 & 5.16 & 5.22 & 5.31 & 5.38 & 5.48 & 5.55 & 5.60 & 5.65 & 5.68 \\
\hline $146-43 R-4(28-36)$ & Vert. & 2.81 & Dolerite & 4.60 & 4.75 & 4.85 & 4.97 & 5.05 & 5.17 & 5.25 & 5.37 & 5.46 & 5.52 & 5.57 & 5.63 \\
\hline & Horz. & 2.87 & Dolerite & 5.07 & 5.15 & 5.20 & 5.26 & 5.30 & 5.39 & 5.44 & 5.53 & 5.60 & 5.63 & 5.66 & 5.68 \\
\hline $146-43 R-4(131-138)$ & Vert. & 2.94 & Dolerite & 5.46 & 5.57 & 5.64 & 5.69 & 5.73 & 5.80 & 5.86 & 5.92 & 5.98 & 6.00 & 6.02 & 6.03 \\
\hline $150-11-2(11-29)$ & Vert. & 2 & e & 40 & 4.65 & 4.75 & 4.80 & 4.85 & 4.93 & 5.01 & 5.11 & 5.18 & 5.25 & 5.31 & 5.36 \\
\hline & Horz. & 2. & Dolerite & 4.65 & 4.82 & 4.92 & 4.99 & 5.04 & 5.13 & 5.19 & 5.29 & 5.36 & 5.43 & 5.48 & 5.50 \\
\hline $150-11-2(74-81)$ & Vert. & 2.56 & Dolerite & 3.68 & 3.85 & 4.08 & 4.18 & 4.28 & 4.42 & 4.52 & 4.67 & 4.79 & 4.88 & 4.97 & 5.06 \\
\hline & Horz. & 2.75 & Dolerite & 4.15 & 4.34 & 4.44 & 4.51 & 4.58 & 4.67 & 4.74 & 4.86 & 4.95 & 5.03 & 5.10 & 5.15 \\
\hline $150-12-1(0-15)$ & Vert. & 2.89 & Dolerite & 4.71 & 4.94 & 5.06 & 5.15 & 5.23 & 5.34 & 5.42 & 5.52 & 5.58 & 5.61 & 5.64 & 5.66 \\
\hline & Horz. & 2.80 & Dolerite & 4.60 & 4.98 & 5.05 & 5.10 & 5.14 & 5.20 & 5.26 & 5.38 & 5.46 & 5.53 & 5.59 & 5.65 \\
\hline $150-12-1(119-131)$ & Vert. & 2.79 & Dolerite & 4.47 & 4.60 & 4.70 & 4.77 & 4.72 & 4.89 & 4.96 & 5.03 & 5.11 & 5.18 & 5.23 & 5.28 \\
\hline & Horz. & 2.69 & Dolerite & 4.66 & 4.70 & 4.73 & 4.75 & 4.77 & 4.82 & 4.87 & 4.95 & 5.02 & 5.10 & 5.11 & 5.20 \\
\hline $150-12-2(26-42)$ & Vert. & 2.78 & Dolerite & 4.60 & 4.86 & 4.96 & 5.04 & 5.08 & 5.18 & 5.26 & 5.38 & 5.48 & 5.54 & 5.57 & 5.58 \\
\hline & Horz. & 2.78 & Dolerite & 4.73 & 4.87 & 4.93 & 4.98 & 5.02 & 4.08 & 5.13 & 5.23 & 5.30 & 5.36 & 5.42 & 5.47 \\
\hline $150-12-2(107-120)$ & Vert. & 2.80 & Dolerite & 4.78 & 5.00 & 5.06 & 5.11 & 5.16 & 5.23 & 5.30 & 5.41 & 5.51 & 5.60 & 5.68 & 5.76 \\
\hline & Horz. & 200 & Dolerite & 4.82 & 5.05 & 5.17 & 5.24 & 5.30 & 5.38 & 5.44 & 5.55 & 5.61 & 5.66 & 5.70 & 5.73 \\
\hline $151-14-1(109-111)$ & Horz. & 2.5 & & 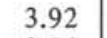 & 4.12 & 4.17 & 4.20 & 4.23 & 4.29 & 4.34 & 4.45 & 4.55 & 4.65 & 4.73 & 4.82 \\
\hline $151-14-1(130-137)$ & Horz. & 2.58 & Basalt & 3.74 & 4.00 & 4.13 & 4.22 & 4.28 & 4.37 & 4.45 & 4.56 & 4.66 & 4.73 & 4.78 & 4.81 \\
\hline $151-15-1(138-153)$ & Vert. & 2.67 & Basalt & 4.08 & 4.18 & 4.21 & 4.24 & 4.27 & 4.32 & 4.38 & 4.49 & 4.60 & 4.68 & 4.77 & 4.85 \\
\hline & Horz. & 2.69 & Basalt & 3.96 & 4.21 & 4.37 & 4.47 & 4.55 & 4.66 & 4.72 & 4.83 & 4.93 & 5.02 & 5.10 & 4.17 \\
\hline 152 & Horz & 2.5 & Racalt & 38 & 4.19 & 4.24 & 4.29 & 4.34 & 4.40 & 4.47 & 4.55 & 4.61 & 4.67 & 4.73 & 4.79 \\
\hline $152-23-1(118-127)$ & Vert. & 2. & & 0 & 4.02 & 4.10 & 4.16 & 4.21 & 4.29 & 4.35 & 4.45 & 4.55 & 4.65 & 4.72 & 4.78 \\
\hline & Horz. & 2.64 & Basalt & 4.07 & 4.28 & 4.38 & 4.45 & 4.50 & 4.59 & 4.66 & 4.76 & 4.83 & 4.87 & 4.89 & 4.91 \\
\hline $152-24-1(11-19)$ & Horz. & 2.72 & Basalt & 4.30 & 4.48 & 4.53 & 4.57 & 4.60 & 4.66 & 4.71 & 4.79 & 4.85 & 4.88 & 4.95 & 4.98 \\
\hline $152-24-2(47-55)$ & Vert. & 2.63 & Basalt & 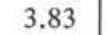 & 3.95 & 4.03 & 4.12 & 4.21 & 4.33 & 4.43 & 4.58 & 4.67 & 4.74 & 4.80 & 4.85 \\
\hline $152-24-2(136-150)$ & Vert. & 2.64 & Basalt & 6 & 3.98 & 4.05 & 4.14 & 4.21 & 4.32 & 4.42 & 4.58 & 4.68 & 4.76 & 4.80 & 4.82 \\
\hline & Horz. & 2.55 & Basalt & 3.39 & 3.69 & 3.84 & 3.95 & 4.01 & 4.17 & 4.28 & 4.44 & 4.54 & 4.61 & 4.66 & 4.68 \\
\hline $153-19-1(140-150)$ & Ver & 2. & Basalt & 4.4 & 4.66 & 4.79 & 4.87 & 4.95 & 5.07 & 5.16 & 5.29 & 5.39 & 5.46 & 5.51 & 5.55 \\
\hline $153-20-1(10-23)$ & Vert. & 2.87 & Basalt & 4.96 & 5.21 & 5.29 & 5.36 & 5.41 & 5.50 & 5.56 & 5.66 & 5.73 & 5.78 & 5.80 & 5.83 \\
\hline & Horz. & 2.86 & Basalt & 4.95 & 5.05 & 5.15 & 5.22 & 5.27 & 5.34 & 5.38 & 5.45 & 5.51 & 5.53 & 5.55 & 5.56 \\
\hline $153-20-1(126-132)$ & Vert. & 2.72 & Basalt & 4.11 & 4.32 & 4.43 & $4.5 \cdot 2$ & 4.60 & 4.71 & 4.79 & 4.91 & 5.00 & 5.09 & 5.17 & 5.25 \\
\hline & Horz & 2.72 & Basalt & 4.12 & 4.34 & 4.46 & 4.55 & 4.63 & 4.76 & 4.85 & 5.00 & 5.12 & 5.21 & 5.29 & 5.37 \\
\hline $153-20-2(6-16)$ & Vert. & 2.72 & Basalt & 4.43 & 4.57 & 4.67 & 4.73 & 4.79 & 4.89 & 4.96 & 5.05 & 5.10 & 5.15 & 5.18 & 5.21 \\
\hline $153-20-2(123-129)$ & Vert. & 2.81 & Basalt & 4.67 & 4.84 & 4.91 & 4.98 & 5.02 & 5.10 & 5.16 & 5.25 & 5.32 & 5.37 & 5.42 & 5.45 \\
\hline
\end{tabular}

${ }^{\mathrm{a}}$ The calculated in situ lithostatic pressure of these samples is approximately $0.5 \mathrm{~kb}$.

and composed of glomeroporphyritic plagioclase set in a groundmass of plagioclase, pyroxene, oxide grains and interstitial, micaceous, alteration material. The amygdules are filled with a very fine-grained micaceous substance (see Donnelly, "Basalts and Dolerites," for a complete discussion of petrology). The measured velocities of the seven samples range from 3.69 to $4.48 \mathrm{~km} / \mathrm{sec}$ at $0.25 \mathrm{~kb}$ to 4.68 to $4.91 \mathrm{~km} / \mathrm{sec}$ at $7 \mathrm{~kb}$ (Table 1). The calculated in situ confining pressure of the basalt at Site 152 is approximately $0.4 \mathrm{~kb}$. The measured velocity range of the seven specimens at $0.4 \mathrm{~kb}$ is 3.78 to $4.51 \mathrm{~km} / \mathrm{sec}$ and the average is $4.13 \mathrm{~km} / \mathrm{sec}$.

At Site 153, located at the southern end of the Beata Ridge, six meters of Coniacian basalt were sampled 758 
meters below the sediment-water interface. The upper basalt (Core 19) is fine-grained and composed of plagioclase laths intergrown with pyroxene and interstitial oxide grains and glass (or altered glass-saponite). Although composed of the same mineral assemblage as the upper basalt, the lower basalt sample (Core 20) is coarser grained and is characterized by subophitic and intergranular textures (see Donnelly, "Basalts and Dolerites," for a complete discussion of petrology). The measured velocities of the seven samples range from 4.32 to $5.21 \mathrm{~km} / \mathrm{sec}$ at $0.25 \mathrm{~kb}$ to 5.21 to 5.83 $\mathrm{km} / \mathrm{sec}$ at $7 \mathrm{~kb}$. The calculated in situ confining pressure of the basalt at Site 153 is approximately $0.5 \mathrm{~kb}$. The measured velocity range of seven specimens at $0.5 \mathrm{~kb}$ is 4.43 to $5.29 \mathrm{~km} / \mathrm{sec}$ and the average is $4.81 \mathrm{~km} / \mathrm{sec}$.

The mineral constituents of the igneous rocks recovered at Sites 146, 151, 152, and 153 are similar. The textures and the degrees of alteration of the igneous samples, however, are variable. The dolerite samples of Sites 146 and 150 are characterized by subophitic and ophitic textures; the basalt of Site 153 is characterized by intergranular and subophitic textures; the basalts of Sites 151 and 152 are characterized by glomeroporphyritic clusters set in a fine-grained matrix with amygdules. The twenty-two dolerite samples from Site 146 had the highest average compressional wave velocities $(5.08 \mathrm{~km} / \mathrm{sec}$ at $0.5 \mathrm{~kb})$. The twelve dolerite samples from Site 150, although texturally similar to the samples of Site 146, were more severely altered and the average compressional wave velocities are lower $(4.82$ $\mathrm{km} / \mathrm{sec}$ at $0.5 \mathrm{~kb}$ ). The seven intergranular to subophitic basalt specimens from Site 153 have measured compressional wave velocities similar to those of the dolerite at Site $150(4.81 \mathrm{~km} / \mathrm{sec}$ at $0.5 \mathrm{~kb})$. The altered, glomeroporphyritic, fine-grained, amygdaloidal basalts of Sites 151 (4 samples) and 152 (7 samples) have measured compressional wave velocities (Site $151-4.22 \mathrm{~km} / \mathrm{sec}$ at $0.5 \mathrm{~kb}$; Site 152 $-4.16 \mathrm{~km} / \mathrm{sec}$ at $0.5 \mathrm{~kb}$ ), that are lower than those of the coarser-grained basalt of Site 153 and the dolerite of Sites 146 and 160 . These results suggest that an increase in grain size raises the compressional wave velocity and an increase in the degree of alteration (low temperature) lowers the compressional wave velocity of rocks of similar composition.

The depth at which the basalt and dolerite rocks were recovered at the five sites correlates with the deepest acoustic reflector defined in the Caribbean Basin which has been called B"' by Ewing et al. (1968). Published seismic refraction results define a 1-to-2-km-thick layer below B" which has velocities ranging from 3.5 to $4.6 \mathrm{~km} / \mathrm{sec}$ (Edgar et al., 1971). Recently, analysis of sonobuoy data from the Venezuela and Colombia Basins reveals higher velocities (4.5-5.3 $\mathrm{km} / \mathrm{sec})$ for the material lying below acoustic Horizon B" (Ludwig, personal communication). The calculated in situ confining pressure for this layer below B" is approximately 0.5 to $1.0 \mathrm{~kb}$. Inspection of the measured velocities of the dolerite and basalt samples collected during Leg 15 (see Table 1) shows that at confining pressures of 0.5 to $1.0 \mathrm{~kb}$ the dolerite (Sites 146 and 150) and the intergranular basalt (Site 153) have velocities ranging from 4.08 to $5.73 \mathrm{~km} / \mathrm{sec}$. The measured velocities of the fine-grained amygdaloidal basalts of Sites 151 and 152 have measured velocities at 0.5 to $1.0 \mathrm{~kb}$ of 3.84 to $4.60 \mathrm{~km} / \mathrm{sec}$.
The majority of the measured velocities of basalt and dolerite recovered during Leg 15 are compatible with the velocities recorded by seismic refraction techniques for the material lying below B" and above the upper crustal layer of the Caribbean basin. These results suggest that the material below B" may be composed of a thick sequence of basalt and dolerite or an assemblage of basalt and dolerite sills sandwiched between sedimentary rocks. It must be remembered, however, that the 4.0 to $5.0-\mathrm{km} / \mathrm{sec}$ range in compressional wave velocity at 0.5 to $1.0 \mathrm{~kb}$ is not a unique velocity range restricted to basalt. A wide range of consolidated sedimentary rocks have measured velocities in this range (see Anderson and Lieberman, 1968). Consequently, until the material below B" is sampled directly by dredging of tectonic escarpments or drilling, the composition of the 3.5 to $5.3-\mathrm{km} / \mathrm{sec}$ layer will be unresolved.

Seismic refraction results record crustal velocities beneath the 3.5 to $5.3-\mathrm{km} / \mathrm{sec}$ layer (Officer et al., 1959; Ewing et al., 1960; Edgar et al., 1971). The Grenada Trough, Aves Ridge, Venezuelan Basin and part of the Colombian Basin are characterized by velocities in the 6.0 to $6.3 \mathrm{~km} / \mathrm{sec}$ range. Under the Beata Ridge, Nicaragua Plateau and part of the Colombia Basin, the upper crustal layer is characterized by velocities in the $5.0-5.5 \mathrm{~km} / \mathrm{sec}$ range. The intergranular basalt and diabase specimens recovered during Leg 15 have measured velocities (see Table 1) at 1 to $2 \mathrm{~kb}$ (calculated in situ confining pressure) that are compatible with the published seismic refraction velocities recorded for the 5.0 to $5.5-\mathrm{km} / \mathrm{sec}$ crust under the Beata Ridge, Nicaragua Plateau and part of the Colombia Basin. Basalt and dolerite dredged from the western escarpment of the Beata Ridge also have measured velocities in the 5.0 to $5.5-\mathrm{km} / \mathrm{sec}$ range (Fox et al., 1970). The velocities of the basalts and diabase recovered during Leg 15 , however, are too low to be considered as a possible constituent of the 6.0 to $6.3-\mathrm{km} / \mathrm{sec}$ layer which characterizes the upper crustal layer of the Grenada Trough, Aves Ridge and Venezuelan Basin. Granodiorite dredged from the southern end of the Aves Ridge has measured velocities in the 6.0 to $6.3-\mathrm{km} / \mathrm{sec}$ range at $1.2 \mathrm{~kb}$ confining pressure (Fox et al., 1971). Also, greenschist metabasalt (Naenriched plagioclase, epidote, quartz, chlorite, and actinolite) has measured velocities in the 6.0 to $6.3-\mathrm{km} / \mathrm{sec}$ range at 1-2 kb (Christensen and Shaw, 1970; Fox et al., 1971). Although metabasalts of this type have been recovered frequently in dredges from tectonic escarpments associated with the mid-oceanic ridge, these rock types have not been recovered from escarpments within the Caribbean. Until more samples of the 6.0 to $6.3-\mathrm{km} / \mathrm{sec}$ upper crustal layer of the Caribbean are recovered by drilling and dredging, the composition of the layer will remain debatable.

\section{ACKNOWLEDGMENTS}

The authors wish to express their appreciation to $\mathrm{T}$. Edgar for providing us with the opportunity to study specimens of Leg 15 . We gratefully acknowledge the assistance of A. Poggi in the laboratory. Support for this research came from National Science Foundation grants GA 30618 (E.S. and P. J. F.), GA 27281 (P. J. F.) and Office of Naval Research grant TO4-N00014-67-A-010-004 (P. J. F.). 


\section{REFERENCES}

Anderson, O. L and Liebermann, R. C., 1968. Sound velocities in rocks and minerals: Experimental methods, extrapolations to very high pressures, and results. In Physical Acoustics. W. P. Mason (Ed.). New York (Academic Press). 4 (part 13) 330.

Christensen, N. and Shaw, G., 1970. Elasticity of mafic rocks from the Mid-Atlantic Ridge. Geophys. J. Roy. Astron.Soc. 20, 271.

Edgar, N. T., Ewing., J. I. and Hennion, J., 1971. Seismic refraction and reflection in Caribbean Sea. Bull. Am. Assoc. Petrol. Geologists. 55 (no. 6), 833.

Ewing, J., Antoine, J. and Ewing, M., 1960. Geophysical measurements in the western Caribbean Sea and in the Gulf of Mexico. J. Geophys. Res. 654087.

Ewing, J., Talwani, M. and Ewing, M., 1968. Sediments of the Caribbean. Symp. Tropical Oceanog. Univ. of Miami. 5,88 .

Fox, P. J., Ruddiman, W. F., Ryan, W. B. F. and Heezen, B. C., 1970. The geology of the Caribbean crust, I: Beata Ridge. Tectonophysics. 10, 495 .
Fox, P. J., Schreiber, E. and Heezen, B. C., 1971. The geology of the Caribbean crust: Tertiary sediments, granitic and basic rocks from the Aves Ridge. Tectonophysics. 12,89 .

Fox, P. J., Peterson, J. J. and Schreiber, E., 1971. The compressional wave velocity characteristics of oceanic rocks (Abstracts with Programs). Geol. Soc. of Am. 3 (no. 7), 572 .

Mattaboni, P. and Schreiber, E., 1967. Method of pulse transmission measurements for determining sound velocities. J. Geophys. Res. 72, 5160.

Officer, C. B., Hennion, J. F., Harkrider, D. G. and Miller, D. E., 1959. Geophysical investigations in the eastern Caribbean - summary of the 1955 and 1956 cruises. In Physics and Chemistry of the Earth. L. H. Ahrens (Ed.) Oxford (Pergamon Press) 3, 17.

Schreiber, E., Fox, P. J. and Peterson, J. J., 1972. Compressional sound velocities in semi-indurated sediments and basalts. In Hollister, C. P., Ewing, J. I. et al. 1973. Initial Reports of the Deep Sea Drilling Project, Volume XI. Washington (U.S. Gov. Printing Office) 723. 